\title{
The Phenomenon of Postoperative Sensitivity and Composite Restorations - A Review
}

\author{
Usman Anwer Bhatti
}

\author{
BDS, FCPS
}

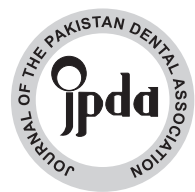

The number of composite restorations delivered to patients is on the rise. Despite the improvement in mechanical properties of modern composites, the task of providing a functional restoration is at times compromised due to the problem of postoperative sensitivity associated with these restorations. An understanding of the potential causes of postoperative sensitivity will enable clinicians to adopt a technique which minimizes the risk of development of postoperative sensitivity and subsequently ensure restoration longevity. This article reviews the literature to explain the common reasons for development of this phenomenon. The continuous development and introduction of newer materials in the market creates a lack of long term clinical data pertaining to a particular type of composite and adhesive system. Although the newly developed materials have shown promising results in terms of reduced postoperative sensitivity, a systematic review and meta-analysis is required for evaluating the findings from the recently conducted clinical studies on the subject of postoperative sensitivity.

KEY WORDS: Adhesives; Composite resin; Dentin permeability; Polymerization; Pain; Smear layer

HOW TO CITE: Bhatti UA. The phenomenon of postoperative sensitivity and composite restorations - a review. J Pak Dent Assoc 2019;28(1):33-40.

DOI: https://doi.org/10.25301/JPDA.281.33

Received: 27 June 2018, Accepted: 14 December 2018

\section{INTRODUCTION}

$r^{\prime}$ omposite resins have become a popular restorative material substituting amalgam, with longitudinal studies showing comparable results in terms of long term clinical performance. ${ }^{1}$ However, cross sectional studies have observed a disparity in the clinical performance of these two materials which can be explained in part by the lack of undergraduate training for composite restorations when compared with amalgam. ${ }^{2}$ Among the different reasons for the failure of composite restorations, postoperative sensitivity is a very common phenomenon, whereby the clinician has to deal with an embarrassing situation while trying to reassure a suffering patient. ${ }^{3}$ Studies have reported the frequency of postoperative sensitivity to be as low as $5 \%$ and as high as $30 \%{ }^{4,5,6}$ In order to avoid such instances it is important to understand the reasons for development of postoperative sensitivity following placement of composite restorations. This article reviews the reasons for development of postoperative sensitivity as identified in the literature.

The literature has theorized various causes of postoperative sensitivity, for example:

1. Polymerization shrinkage

2. Marginal gaps

1. Assistant Professor, Department of Operative Dentistry, Islamabad Medical and Dental College.

Corresponding author: “Dr. Usman Anwer Bhatti” < drusmananwer@gmail.com >
3. Suboptimal adhesion

4. Inadequate polymerization

5. Unfavourable C-factor and residual dentin thickness

6. Pre-existing tooth related factors, such as cracks

\section{Polymerization shrinkage}

Many of the problems associated with composite resins stem from their inherent tendency to undergo shrinkage. Resin based materials like composites set by a polymerization reaction, which results in a shrinkage of varying degree. ${ }^{7}$ This polymerization shrinkage can either, generate stress at the bonding interface, transfer stress to the adjacent tooth structure or generate residual stress in the final set material. ${ }^{8}$ Stresses at the interface can potentially weaken the bond, particularly in cases where cavosurface margins exist entirely in dentin. ${ }^{9}$ Depending on the compliance of the remaining tooth structure, varying degrees of cuspal deflection has been observed and this may lead to enamel crazes or fracture lines. ${ }^{8,10,11}$ Cracks may increase flexure of tooth structure under occlusal loading or become an avenue for bacterial ingress. Moreover, movement of dentinal fluid in association with the cuspal deflection can potentially induce postoperative sensitivity depending on the rate and direction of fluid movement. ${ }^{12,13}$

There have been numerous improvements in material formulation of composite resins to improve clinical performance. In clinical dentistry two most notable areas of 
improvement have been the Table 1: Summary of clinical studies that evaluated postoperative sensitivity in relation to different minimization of the amount of types of composites and adhesive strategy

polymerization shrinkage and reduction in the development of shrinkage stress. The development of silorane based composites with the advantage of reduced polymerization shrinkage of about $1 \%$ have provided hope for minimizing the detrimental effects like postoperative sensitivity. However, a recent systematic review and meta analysis of the available clinical studies on siloranes concluded that silorane based composites are not better than conventional methacrylate based composites in terms of the observed clinical performance in class I and class II restoration of permanent posterior teeth. ${ }^{14}$ Table 1 summarizes the results of different clinical studies on silorane based composites and postoperative sensitivity. ${ }^{15-25}$

Bulkfill composites with shrinkage stress relievers and polymerization modulators have been introduced to counter the development of shrinkage stress and in vitro studies have shown these materials exhibit less shrinkage stress than conventional composite resins. ${ }^{26}$ The results of clinical studies evaluating the postoperative sensitivity associated with the use of bulkfill composites are shown in Table 1. A recent double blind randomized clinical trial while investigating the effect of filling technique on occurrence and intensity of postoperative sensitivity concluded that the risk and intensity of postoperative

\begin{tabular}{|c|c|c|c|c|c|c|}
\hline Authors & $\begin{array}{c}\text { Publication } \\
\text { year }\end{array}$ & $\begin{array}{l}\text { Observation } \\
\text { period }\end{array}$ & Study design & $\begin{array}{l}\text { Sample } \\
\text { size }\end{array}$ & $\begin{array}{c}\text { Materials/ adhesive } \\
\text { strategy }\end{array}$ & $\begin{array}{c}\text { Post } \\
\text { operative } \\
\text { sensitivity }\end{array}$ \\
\hline $\begin{array}{l}\text { Baracco B } \\
\text { and } \\
\text { others }^{15}\end{array}$ & 2012 & 1 year & $\begin{array}{l}\text { Randomized } \\
\text { Control trial }\end{array}$ & 75 & $\begin{array}{l}\text { Filtek silorane vs Filtek Z250 } \\
\text { (3M ESPE, St Paul, MN, USA)/ } \\
\text { Adper Scotchbond } 1 \text { XT vs } \\
\text { Adper Scotchbond SE (3M } \\
\text { ESPE, St Paul, MN, USA) }\end{array}$ & $0 \%$ \\
\hline $\begin{array}{l}\text { Mahmoud } \\
\text { SH and } \\
\text { others }^{16}\end{array}$ & 2014 & 3 years & $\begin{array}{l}\text { Randomized } \\
\text { control trial }\end{array}$ & 156 & $\begin{array}{l}\text { Filtek P90 (3M ESPE, St Paul, } \\
\text { MN, USA) vs Quixfil (Dentsply } \\
\text { DeTrey; York, PA, USA)/ Filtek } \\
\text { P90 adhesive (3M/ESPE; } \\
\text { Seefeld, Germany) vs Prime \& } \\
\text { bond NT (Dentsply DeTrey) }\end{array}$ & $3 \%$ \\
\hline $\begin{array}{l}\text { Van Dijkin } \\
\text { JW and } \\
\text { others }^{17}\end{array}$ & 2014 & 3 years & $\begin{array}{l}\text { Randomized } \\
\text { control trial }\end{array}$ & 104 & $\begin{array}{c}\text { SDR (Dentsply DeTrey; } \\
\text { Konstanz, Germany) } \\
\text { vs Ceram X mono (Dentsply } \\
\text { DeTrey) / XenoV (Dentsply } \\
\text { DeTrey; Konstanz, Germany) }\end{array}$ & $<1 \%$ \\
\hline $\begin{array}{l}\text { Yaman } \\
\text { and } \\
\text { others }^{18}\end{array}$ & 2014 & 3 years & $\begin{array}{l}\text { Randomized } \\
\text { control trial }\end{array}$ & 121 & $\begin{array}{l}\text { Filtek silorane (3M ESPE AG, St } \\
\text { Paul, MN, USA) vs Ceram X } \\
\text { mono (Dentsply DeTrey, } \\
\text { Konstanz, Germany)/ Clearfil } \\
\text { SE (Kurraray America, NY) vs } \\
\text { XP Bond (Dentsply DeTrey, } \\
\text { Konstanz, Germany) }\end{array}$ & $0 \%$ \\
\hline $\begin{array}{l}\text { Van Dijkin } \\
\text { JW and } \\
\text { others }^{19}\end{array}$ & 2015 & 15 years & $\begin{array}{l}\text { Randomized } \\
\text { control trial }\end{array}$ & 91 & $\begin{array}{c}\text { InTen-S (IvoclarVivadent, } \\
\text { Schaan,Liechtenstein) vs Point } \\
4 \text { (Kerr, West Collins Orange, } \\
\text { CA, USA) / Excite } \\
\text { (IvoclarVivadent, } \\
\text { Schaan,Liechtenstein) vs } \\
\text { Optibond Solo Plus (Kerr, West } \\
\text { Collins Orange, CA, USA) }\end{array}$ & $<2 \%$ \\
\hline $\begin{array}{l}\text { Van Dijkin } \\
\text { JW and } \\
\text { others }^{20}\end{array}$ & 2016 & 5 years & $\begin{array}{l}\text { Randomized } \\
\text { control trial }\end{array}$ & 183 & $\begin{array}{c}\text { SDR (Dentsply DeTrey; } \\
\text { Konstanz, Germany) vs Ceram } \\
\text { X mono+ (Dentsply DeTrey) / } \\
\text { Xeno V+ (Dentsply DeTrey; } \\
\text { Konstanz, Germany) }\end{array}$ & $0 \%$ \\
\hline $\begin{array}{l}\text { Öztürk- } \\
\text { Bozkurt F } \\
\text { and } \\
\text { others }^{21}\end{array}$ & 2016 & 3 years & $\begin{array}{l}\text { Randomized } \\
\text { control trial }\end{array}$ & 58 & $\begin{array}{l}\text { Filtek silorane (3M ESPE AG, St } \\
\text { Paul, MN, USA) vs Filtek Z550 } \\
\text { (3M ESPE AG)/ Silorane Primer } \\
\text { and Bond (3M ESPE AG, St } \\
\text { Paul, MN, USA) vs Adper Single } \\
\text { bond } 2 \text { (3M ESPE AG) } \\
\end{array}$ & $3.45 \%$ \\
\hline $\begin{array}{c}\text { Yazici AR } \\
\text { and } \\
\text { others }^{22}\end{array}$ & 2017 & 3 years & $\begin{array}{l}\text { Split mouth } \\
\text { design }\end{array}$ & 81 & $\begin{array}{c}\text { Tetric EvoCeram Bulkfill } \\
\text { (Ivoclar Vivadent, Schaan, } \\
\text { Liechtenstein) vs Filtek } \\
\text { Ultimate (3M ESPE, St Paul, } \\
\text { MN, USA)/ Excite F (Ivoclor } \\
\text { Vivadent) vs Adper Single Bond } \\
2 \text { (3M ESPE) } \\
\end{array}$ & $0 \%$ \\
\hline Ayar $\mathrm{MK}^{23}$ & 2017 & - & Retrospective & 72 & $\begin{array}{l}\text { Filtek Bulk fill (3M ESPE, St. } \\
\text { Paul, MN, USA) vs Filtek Z250 } \\
\text { (3M ESPE, St. Paul, MN, USA)/ } \\
\text { Single bond universal (3M } \\
\text { ESPE, St. Paul, MN, USA) }\end{array}$ & $\begin{array}{l}25 \% \text { vs } \\
30.5 \%\end{array}$ \\
\hline $\begin{array}{c}\text { Costa T } \\
\text { and } \\
\text { others }^{24}\end{array}$ & 2017 & $\begin{array}{l}48 \text { hours- } 1 \\
\text { week }\end{array}$ & $\begin{array}{l}\text { Double blind } \\
\text { randomized } \\
\text { control trial }\end{array}$ & 236 & $\begin{array}{l}\text { Tetric EvoCeram bulkfill } \\
\text { (Ivoclar Vivadent, Schaan, } \\
\text { Liechtenstein) Incremental vs } \\
\text { bulkfill/ Tetric N bond (Ivoclar } \\
\text { Vivadent, Schaan, } \\
\text { Liechtenstein) vs Tetric N bond } \\
\text { SE (Ivoclar Vivadent, Schaan, } \\
\text { Liechtenstein) }\end{array}$ & $20.3 \%$ \\
\hline $\begin{array}{l}\text { Heck K } \\
\text { and } \\
\text { others }^{25}\end{array}$ & 2018 & 10 years & $\begin{array}{l}\text { Randomized } \\
\text { control trial }\end{array}$ & 56 & $\begin{array}{l}\text { Quix fill (Dentsply DeTrey, } \\
\text { Konstanz, Germany) vs Tetric } \\
\text { Ceram (Vivadent, Schaan, } \\
\text { Liechtenstein) / Xeno III } \\
\text { (Dentsply DeTrey, Konstanz, } \\
\text { Germany) vs Syntac classic } \\
\text { (Vivadent, Schaan, } \\
\text { Liechtenstein) }\end{array}$ & $1.7 \%$ \\
\hline
\end{tabular}


sensitivity was not associated with the filling technique. ${ }^{24}$

\section{Marginal gap}

The polymerization shrinkage stresses have the potential to create a marginal gap in areas deficient in enamel. It has been proposed that a gap at the tooth- restorative margin is a potential site for bacterial ingress as well as portal for fluid exchange leading to a movement of dentinal fluid in the tubules and subsequent postoperative sensitivity. ${ }^{27,28}$ Clinical situations with an extension of the cavity margin to dentin, like a deep class II and class V, create a challenge for the placement and adaptation of the composite to the dentinal margin. The formation of a gap along this cavosurface margin can potentially invite postoperative sensitivity, ${ }^{5}$ microleakage and secondary caries in the long run. ${ }^{2}$

However, the results from clinical studies have not been able to establish an unequivocal link between marginal gap and postoperative sensitivity. ${ }^{29,30}$ A systematic analysis of the literature found a lack of correlation between the percentages of margins with gaps and clinical outcomes; moreover, a correlation between microleakage and secondary caries, hypersensitivity and marginal discoloration could not be demonstrated. ${ }^{31}$

Additionally, the adaptation of the composite has been to shown to be affected by the c- factor and compliance of the cavity; with both bulk fills and conventional composites demonstrating inferior adaptation in such clinical situations. ${ }^{32}$ The findings from different in vitro studies concluded that bulkfill composites do not ensure an improvement in marginal adaptation in class II situations, rather the presence or absence of enamel at the restorative margin is a more important predictor of marginal adaptation. ${ }^{33,34,35,36} \mathrm{~A}$ recent systematic review also concluded that application of flowable composites cannot improve microleakage. ${ }^{37}$

Despite the improvement in adhesives, enamel still remains the most favorable substrate for bonding. Although reasonable bond strength can be achieved when bonding to dentin alone, the long term bond longevity is questionable due to the hydrolytic degradation of the hybrid layer components. ${ }^{9}$

\section{Suboptimal adhesion}

The technique sensitive nature of the adhesive procedure for composite restoration demands meticulous attention to detail by the clinician, failing to do so often results in postoperative sensitivity and restoration failure. ${ }^{4}$

A common mechanism for persistent postoperative sensitivity is when a gap forms beneath the restoration and fills with dentinal fluid. When cold or hot stimuli cause contraction or expansion of fluid in this gap, the consequent sudden movement of fluid in the dentinal tubules causes pain. ${ }^{28}$ This gap formation beneath the restoration could be either from a void in the composite material being placed on the floor of the cavity, the pulling away of composite from pulpal floor due to shrinkage stress ${ }^{38}$ or it could be a gap in the hybrid layer due to insufficient resin infiltration resulting in the formation of a "hybridoid layer". 39

Moreover, even the use of bulk fill flowable composites has not been able to eradicate the formation of gaps over the internal walls of the restored cavity, ${ }^{40}$ while the use of the traditional incremental technique with conventional composite has demonstrated a better internal adaptation. ${ }^{41}$ The research on the benefits of applying a flowable composite over the pulpal floor for the sake of eliminating postoperative sensitivity has shown conflicting results. However, a recent Cochrane review of the literature has deemed the evidence "low quality" and discredited the notion of perceived benefit of using flowable liners under composite restorations. ${ }^{42}$ It has been identified that the inadequate permeation of the demineralized dentin during the restorative procedure is a significant contributor to postoperative sensitivity. The risk of postoperative sensitivity and development of "hybridoid layer" has been regarded higher with etch and rinse adhesives as compared to self-etch adhesives due to the elimination of the smear layer in the former and the simultaneous demineralization and resin infiltration in the latter. ${ }^{43}$ The results of clinical trials investigating the role of adhesive strategy in causing postoperative sensitivity have shown mixed results with some studies ${ }^{24,43,44,45}$ claiming no association between the two while others ${ }^{46,47}$ have reported a statistically significant difference in the postoperative sensitivity and adhesive approach. However, meta-analysis and systematic reviews have found no significant association of bonding strategy with the risk and intensity of postoperative sensitivity. ${ }^{48,49}$ The details of different clinical studies comparing adhesive strategies in relation of postoperative sensitivity are summarized in Table 2.

Irrespective of the adhesion strategy used, the presence of a collagen matrix without any resin support is vulnerable to accelerated aging and degradation. ${ }^{9,50}$ Quality of substrate available for adhesion varies across the prepared tooth surface, with areas of caries affected dentin, sclerosis and high tubular density present an adhesive challenge due to a difference in water and mineral content. ${ }^{9}$ Presence of caries affected dentin at the marginal interface of the restoration makes it an unsuitable substrate for predictable adhesion and marginal adaptation contributing to postoperative sensitivity. 5,9

\section{Inadequate polymerization}

Even the stiffest composites are relatively flexible in comparison to the stiffness of tooth enamel, as evident by 
the difference in the modulus of Table 2: Summary of clinical studies that evaluated postoperative sensitivity in relation to different elasticity. ${ }^{51}$ The flexure of composite restoration in relation to the tooth can produce pressure changes in the dentinal tubular fluid and a subsequent fluid movement can in turn provoke pain on chewing. ${ }^{2}$ However, composites applied in sufficient bulk rarely exhibit flexure of this magnitude to induce sensitivity on biting unless the degree of polymerization of the material was not in the acceptable limits, leading to a "soggy bottom" phenomenon. ${ }^{53}$

Clinical situations often require placement of composite in deep cavities where if adequate intensity of the curing light is not provided then the in situ polymerization of the adhesive resins and formation of the hybrid layer is jeopardized leading to a premature bond failure and postoperative sensitivity. ${ }^{54}$ The placement and subsequent curing of conventional composites in bulk can result in a similar situation, whereby complete polymerization of the material to the entire depth is not achieved. However, modern bulkfill composites have demonstrated a promising degree of polymerization in relation to conventional composites $^{55,56}$ and clinical studies on comparison between bulk and incremental filling show no significant difference in the occurrence of reported $\mathrm{p}$ o $\mathrm{s} \mathrm{t}$ o $\mathrm{p}$ e $\mathrm{r}$ a $\mathrm{t} \mathrm{i} \mathrm{V}$ e

\begin{tabular}{|c|c|c|c|c|c|}
\hline Authors & $\begin{array}{l}\text { Observation } \\
\text { period }\end{array}$ & Materials tested & $\begin{array}{l}\text { Adhesive } \\
\text { strategy }\end{array}$ & $\begin{array}{l}\text { No. of } \\
\text { restorations } \\
\text { evaluated }\end{array}$ & Conclusion \\
\hline Costa T et al ${ }^{24}$ & $\begin{array}{l}48 \text { hours- } 1 \\
\text { week }\end{array}$ & $\begin{array}{l}\text { Tetric } \mathrm{N} \text { bond (Ivoclar } \\
\text { Vivadent, Schaan, } \\
\text { Liechtenstein) vs Tetric } \\
\mathrm{N} \text { bond SE (Ivoclar } \\
\text { Vivadent, Schaan, } \\
\text { Liechtenstein) }\end{array}$ & $\begin{array}{l}2 \text { step etch } \\
\text { and rinse } \\
\text { vs } \\
1 \text { step self } \\
\text { etch }\end{array}$ & 236 & $\begin{array}{c}\text { No statistically } \\
\text { significant difference } \\
\text { at } 1 \text { week }\end{array}$ \\
\hline $\begin{array}{l}\text { Perdigao J et } \\
\mathrm{al}^{43}\end{array}$ & 6 months & $\begin{array}{c}\text { Clearfil Se Bond } \\
\text { (Kurraray America, NY) } \\
\text { vs } \\
\text { Prime \& Bond NT } \\
\text { (Dentsply Caulk, } \\
\text { Milford, Del.) } \\
\end{array}$ & $\begin{array}{l}2 \text { step self } \\
\text { etch } \\
\text { vs } \\
2 \text { step etch } \\
\text { and rinse } \\
\end{array}$ & 66 & $\begin{array}{c}\text { No statistically } \\
\text { significant difference } \\
\text { at } 6 \text { months }\end{array}$ \\
\hline Scotti N et al ${ }^{44}$ & 1 week & $\begin{array}{c}\text { All bond } 3 \text { (Bisco } \\
\text { Schaumburg, IL, USA.) } \\
\text { vs } \\
\text { Clearfil protect bond } \\
\text { (Kurraray, Osaka, } \\
\text { Japan) }\end{array}$ & $\begin{array}{l}3 \text { step etch } \\
\text { and rinse } \\
\text { vs } \\
2 \text { step self } \\
\text { etch }\end{array}$ & 204 & $\begin{array}{c}\text { No statistically } \\
\text { significant difference }\end{array}$ \\
\hline $\begin{array}{l}\text { Browning Wd } \\
\text { et al }^{45}\end{array}$ & 13 weeks & $\begin{array}{l}\text { Single bond (3M ESPE } \\
\text { Dental Products, St } \\
\text { Paul, MN, USA) vs } \\
\text { Adper prompt (3M } \\
\text { ESPE Dental Products, } \\
\text { St Paul, } \\
\text { MN, USA) } \\
\end{array}$ & $\begin{array}{l}2 \text { step etch } \\
\text { and rinse } \\
\text { vs } \\
1 \text { step self } \\
\text { etch }\end{array}$ & 209 & $\begin{array}{c}\text { No statistically } \\
\text { significant difference }\end{array}$ \\
\hline Yousaf A et al ${ }^{46}$ & 1 week & $\begin{array}{c}\text { Eco-etch } \\
\text { (Ivoclar Vivadent, } \\
\text { Schaan, Liechtenstein) } \\
\text { vs } \\
\text { Adhese One (Ivoclar } \\
\text { Vivadent, Schaan, } \\
\text { Liechtenstein) }\end{array}$ & $\begin{array}{l}2 \text { step etch } \\
\text { and rinse } \\
\text { vs } \\
1 \text { step self } \\
\text { etch }\end{array}$ & 70 & $\begin{array}{l}\text { Less postoperative } \\
\text { sensitivity with self } \\
\text { etch at } 1 \text { week }\end{array}$ \\
\hline Amin $\mathrm{M}$ et $\mathrm{al}^{47}$ & 1 week & $\begin{array}{c}\text { Prime bond NT } \\
\text { (Dentsply Caulk, } \\
\text { Milford, Del.) } \\
\text { vs } \\
\text { L-Pop (3M ESPE Dental } \\
\text { Products, St Paul, MN, } \\
\text { USA) }\end{array}$ & $\begin{array}{l}2 \text { step etch } \\
\text { and rinse } \\
\text { Vs } \\
\text { self etch }\end{array}$ & 80 & $\begin{array}{l}\text { Less postoperative } \\
\text { sensitivity with Etch } \\
\text { and rinse at } 4 \text { days }\end{array}$ \\
\hline
\end{tabular}

Table 3: Summary of clinical studies on postoperative sensitivity in relation to cavity type

\begin{tabular}{|c|c|c|c|}
\hline Authors & Observation period & Cavity type & $\begin{array}{c}\text { Postoperative } \\
\text { Sensitivity }\end{array}$ \\
\hline Bhatti UA et al ${ }^{4}$ & 2 days & Class I & $13 \%$ \\
\hline Briso ALF et al ${ }^{5}$ & 90 days & $\begin{array}{c}\text { Class I, Class II } \\
(\mathrm{MO} / \mathrm{DO}), \text { Class II } \\
\text { (MOD), }\end{array}$ & $\begin{array}{c}5 \%, 15 \%, 26 \% \\
\text { respectively }\end{array}$ \\
\hline Ayar KM ${ }^{23}$ & 30 days & Class II & $28.6 \%$ \\
\hline Opdam NJ et al ${ }^{29}$ & 49 days & Class I & $14 \%$ \\
\hline Auschill TM et al ${ }^{53}$ & 14 days & All types & $6 \%$ \\
\hline Unemori M et al ${ }^{63}$ & - & All types & $11 \%$ \\
\hline
\end{tabular}
sensitivity. ${ }^{22,23,24,25}$

pulp. ${ }^{57}$ Monomer elution from the set composites has been

In terms of the biological properties of the composite resins, the process of polymerization is not complete in the set material; $25-50 \%$ of the monomer double bonds remain unreacted and this monomer has the potential to irritate the investigated under different conditions and it may take place either due to incomplete polymerization and/or material degradation, thus highlighting the importance of adequate polymerization to minimize the adverse effects from residual 
monomer like pulpal irritation and postoperative sensitivity. However, we cannot prevent material degradation in the oral environment and the eluted monomer can produce ill effects in the pulp. Luckily, the detrimental effects of the residual monomer are inversely proportional to the residual dentin thickness. ${ }^{58}$

\section{Unfavourable C-factor and residual dentin thickness}

The occurrence of postoperative sensitivity can be theorized to occur more frequently in the posterior teeth than the anterior. This can be explained by the difference in configuration of the cavities prepared on anterior and posterior teeth. The C-factor (ratio of bonded to unbonded surfaces) influences the ability of the unpolymerized portion of the composite to compensate for the shrinkage stresses. ${ }^{59}$ As understood the greater $\mathrm{C}$-factor of the cavities prepared in the posterior teeth results in reduced compensation for shrinkage stress and leads to greater stress accumulation at the bonding interface, initiating the sequel of microleakage and sensitivity. ${ }^{60}$ The relatively large size of the cavities made in the posterior teeth require a larger bulk of the composite to restore them, the added bulk also contributes to an increased polymerization shrinkage and shrinkage stress. ${ }^{61}$ However, clinical studies fail to demonstrate this association of $\mathrm{C}$-factor or cavity type with postoperative sensitivity. ${ }^{24,52}$ The frequency of postoperative sensitivity as reported in different clinical studies in relation to the type of cavity is shown in Table 3.,5,23,29,52,62

Another possible reason for postoperative sensitivity could be the increased cavity depth or reduced thickness of residual dentin. As the cavity preparation depth increases the tubular density is also increased making it more challenging to control dentin wetness and ensure optimal adhesion. ${ }^{9}$ The application of the etchant in such deep cavities as part of the etch and rinse approach removes the smear layer and increases the dentin permeability making the tooth vulnerable to postoperative sensitivity if adequate sealing of tubules is not achieved by hybridization. Initially it was believed that the use of acid etchants on the dentin can irritate the pulp but Fusayama's total etch procedure eventually helped alleviate any concerns pertaining to acid etching of dentin. ${ }^{63}$ The higher percentage of postoperative sensitivity reported in multi surface restorations as seen in Table 3 could be explained by the greater removal of tooth structure and reduction in residual dentin thickness. ${ }^{24}$

The placement of composite restorations in close proximity to the pulp without an appropriate bonded liner/base would increase the risk of postoperative sensitivity in case of a compromised adhesion resulting from a failure in the hybridization process. Clinical studies on the other hand observed that a reduction of the residual dentin thickness in deep cavities was found to be associated with greater postoperative sensitivity irrespective of the presence or absence of a cavity liner. ${ }^{23,62}$ Although, the literature in the past has been split over the use of a resin modified glass ionomer (RMGI) base/ liner beneath composite restorations; in deep cavities with questionable bonding substrates placement of a RMGI base/liner has been regarded as a prudent practice. ${ }^{62,64}$ However, a recent Cochrane review concluded that the evidence regarding the use of liners in class I and II is inconsistent and low quality. ${ }^{65}$

\section{Pre-existing tooth related factors}

Prior to delivering a restoration to any tooth, thorough investigation should be carried out to exclude the presence of any pre-existing cracks or pulpal inflammation. Cracks can develop in the tooth due to masticatory insults over a period of time and can create a diagnostic puzzle. ${ }^{66}$ Restoring cavities with an intercuspal width exceeding one quarter are at an increased risk of crack development. ${ }^{67}$ Following cavity preparation any visible crack should be identified and the patient informed accordingly, as symptoms arising from a cracked tooth can mimic reversible pulpitis ${ }^{68}$ but may not be resolved with composite restoration. A clinical study evaluating the resolution of symptomatic cracked teeth following adhesive composite restorations with or without cuspal coverage reported only $50 \%$ teeth to be symptom free on clinical examination..$^{69}$ Hence, restoration of a tooth with an unidentified crack can even result in symptoms that can be confused with postoperative sensitivity. ${ }^{70}$

\section{CONCLUSION}

The development of modern adhesives combined with the improvement in handling of composites by the clinicians has resulted in a marked reduction of postoperative sensitivity. However, the occurrence of postoperative sensitivity is still a threat to the survival of the composite restorations along with bulk fracture, secondary caries and surface wear. ${ }^{43}$ In this article, following the review of literature, various reasons were explained for the phenomenon of postoperative sensitivity associated with composite restorations. An understanding of these reasons is important for the dental practitioner to avoid the development of postoperative sensitivity in the delivered restorations so they can survive and provide service to the patient.

The perpetual development of new composite resin materials creates a scarcity of long term clinical data on a particular type of material. A systematic review and metaanalysis is required for understanding the clinical implications of the results from the plethora of clinical studies on the 
subject of postoperative sensitivity.

\section{CONFLICT OF INTEREST/ FINANCIAL DISCLOSURE}

The author denies any plausible conflict of interest. The author denies any financial interest in the subject matter or materials discussed in this manuscript.

\section{REFERENCES}

1. Van Dijken JW. Direct resin composite inlays/onlays: an 11 year follow-up. J Dent. 2000;28:299-230 https://doi.org/10.1016/S0300-5712(00)00010-5

2. Opdam NJ, Bronkhorst EM, Roeters JM, Loomans BA. A retrospective clinical study on longevity of posterior composite and amalgam restorations. Dent Mater. 2007;23:2-8 https://doi.org/10.1016/j.dental.2005.11.036

3. Rodolpho PAR, Cenci MS, Donassollo TA, Logue'rcio AD, Demarco FF. A clinical evaluation of posterior composite restorations: 17-year findings. J Dent. 2006;34:427-35 https://doi.org/10.1016/j.jdent.2005.09.006

4. Bhatti UA, Ahmed A, Javed Q. Frequency of postoperative sensitivity in posterior class I composite restorations. Pak Oral Dent J. 2014;34:53235

5. Briso AL, Mestrener SR, Delicio G, Sundfeld RH, Bedran-Russo AK, de Alexandre RS, Ambrosano GM. Clinical assessment of postoperative sensitivity in posterior composite restorations. Oper Dent. 2007;32:421-26

https://doi.org/10.2341/06-141

6. Casselli DS, Martins LR. Postoperative sensitivity in Class I composite resin restorations in vivo. J Adhes Dent. 2006;8:53-8

7. Ferracane JL. Developing a more complete understanding of stresses produced in dental composites during polymerization. Dent Mater. $2005 ; 21: 36-42$

https://doi.org/10.1016/j.dental.2004.10.004

8. Kim ME, Park SH. Comparison of premolar cuspal deflection in bulk or in incremental composite restoration methods. Oper Dent. 2011;36:326-34

https://doi.org/10.2341/10-315-L

9. Tjaderhane L. Dentin Bonding: Can We Make it Last? J Op Dent. 2015;40-1:4-18

https://doi.org/10.2341/14-095-BL

10. Tantbirojn D, Versluis A, Pintado MR, DeLong R, Douglas WH. Tooth deformation patterns in molars after composite restoration. Dent Mater. 2004;20:535-42

https://doi.org/10.1016/j.dental.2003.05.008

11. Lee SY, Park SH. Correlation between the amount of linear polymerization shrinkage and cuspal deflection. Oper Dent. 2006;31:364-67

https://doi.org/10.2341/05-46

12. Ratih DN, Palamara JE, Messer HH. Dentinal fluid flow and cuspal displacement in response to resin composite restorative procedures. Dent Mater. 2007;23:1405-1411

https://doi.org/10.1016/j.dental.2006.11.029

13. Eick JD \& Welch FH. Polymerization shrinkage of posterior composite resins and its possible influence on postoperative sensitivity. Quintessence Int. 1986;17:103-111

14. Magno MB, Nascimento GC, Rocha YS, Ribeiro BD, Loretto SC, Maia LC. Silorane-based Composite Resin Restorations Are Not Better than Conventional Composites - A Meta-Analysis of Clinical Studies. J Adhes Dent. 2016;18:375-86

15. Baracco B, Perdigao J, Cabrera E, Giraldez I, \& Ceballos L. Clinical evaluation of a low-shrinkage composite in posterior restorations: One-year results. Oper Dent. 2012;37:117-29 https://doi.org/10.2341/11-179-C

16. Mahmoud SH, Ali AK, Hegazi HA. A three-year prospective randomized study of silorane- and methacrylate-based composite restorative systems in class II restorations. J Adhes Dent. 2014;16:285-92

17. Van Dijken JW, Pallesen U. A randomized controlled three year evaluation of "bulk-filled" posterior resin restorations based on stress decreasing resin technology. Dent Mater. 2014;30:e245-51 https://doi.org/10.1016/j.dental.2014.05.028

18. Yaman BC, Do?ruer I, Gümüstas B, Efes BG. Three-year randomized clinical evaluation of a low-shrinkage silorane-based resin composite in non-carious cervical lesions. Clin Oral Investig. 2014; 18(:10711079

https://doi.org/10.1007/s00784-013-1079-z

19. Van Dijken JW, Lindberg A. A 15-year randomized controlled study of a reduced shrinkage stress resin composite. Dent Mater. 2015; 31:1150-1158

https://doi.org/10.1016/j.dental.2015.06.012

20. Van Dijken JW, Pallesen U. Posterior bulk-filled resin composite restorations: A 5-year randomized controlled clinical study. J Dent. 2016;51:29-35

https://doi.org/10.1016/j.jdent.2016.05.008

21. Öztürk-Bozkurt F, Toz T, Kara-Tuncer A, Gözükara-Bag H, Özcan M. Clinical Evaluation of Silorane and Nano-hybrid Resin Composite Restorations in Class II Cavities up to 3 Years. Oper Dent. 2016; 41:599-606

https://doi.org/10.2341/15-259-C

22. Yazici AR, Antonson SA, Kutuk ZB, Ergin E. Thirty-Six-Month Clinical Comparison of Bulk Fill and Nanofill Composite Restorations. Oper Dent. 2017;42:478-485

https://doi.org/10.2341/16-220-C

23. Ayar MK. Postoperative sensitivity after placement of bulk-fill 
posterior restoration. J Res Med Dent Sc. 2017;5:53-58

24. Costa T, Rezende M, Sakamoto A, Bittencourt B, Dalzochio P, Loguercio AD, Reis A. Influence of Adhesive Type and Placement Technique on Postoperative Sensitivity in Posterior Composite Restorations. Oper Dent. 2017;42:143-54 https://doi.org/10.2341/16-010-C

25. Heck K, Manhart J, Hickel R, Diegritz C. Clinical evaluation of the bulk fill composite QuiXfil in molar class I and II cavities: 10year results of a RCT. Dent Mater. 2018;34:e138-e147 https://doi.org/10.1016/j.dental.2018.03.023

26. El-Damanhoury H M, Platt J A. Polymerisation shrinkage stress kinetics and related properties of bulk-fill resin composites. Oper Dent. 2014;39:374-82

https://doi.org/10.2341/13-017-L

27. Deliperi S, Bardwell DN. An alternative method to reduce polymerization shrinkage in direct posterior composite restorations. J Am Dent Assoc. 2002;133:1387-1398 https://doi.org/10.14219/jada.archive.2002.0055

28. Brännström M. Communication between the oral cavity and the dental pulp associated with restorative treatment. Oper Dent. 1984;9:5768

29. Opdam NJ, Feilzer AJ, Roeters JJ, Smale I. Class I occlusal composite resin restorations: in vivo post-operative sensitivity, wall adaptation, and microleakage. Am J Dent. 1998;11:229-34

30. Opdam NJ, Roeters FJ, Feilzer AJ, Verdonschot EH. Marginal integrity and postoperative sensitivity in Class 2 resin composite restorations in vivo. J Dent. 1998;26:555-62 https://doi.org/10.1016/S0300-5712(97)00042-0

31. Heintze SD. Systematic reviews: (1) The correlation between laboratory tests on marginal quality and bond strength. (2) The correlation between marginal quality and clinical outcome. J Adhes Dent. 2007;9 (suppl 1):77-106

32. Han SH, Sadr A, Tagami J, Park SH. Internal adaptation of resin composites at two configurations: Influence of polymerization shrinkage and stress. Dent Mater. 2016;32:1085-1094 https://doi.org/10.1016/j.dental.2016.06.005

33. Campos EA, Ardu S, Lefever D, Jassé FF, Bortolotto T, Krejci I. Marginal adaptation of class II cavities restored with bulk-fill composites. J Dent. 2014;42:575-81

https://doi.org/10.1016/j.jdent.2014.02.007

34. Pecie R, Onisor I, Krejci I, Bortolotto T. Marginal adaptation of direct class II composite restorations with different cavity liners. Oper Dent. 2013;38:E210-20

https://doi.org/10.2341/12-229-L

35. Agarwal RS, Hiremath H, Agarwal J, Garg A. Evaluation of cervical marginal and internal adaptation using newer bulk fill composites: An in vitro study. J Conserv Dent. 2015;18:56-61

https://doi.org/10.4103/0972-0707.148897
36. Roggendorf MJ, Krämer N, Appelt A, Naumann M, Frankenberger R. Marginal quality of flowable 4-mm base vs. conventionally layered resin composite. J Dent. 2011;39:643-647

https://doi.org/10.1016/j.jdent.2011.07.004

37. Boruziniat A, Gharaee S, Sarraf Shirazi A, Majidinia S, Vatanpour M. Evaluation of the efficacy of flowable composite as lining material on microleakage of composite resin restorations: A systematic review and meta-analysis. Quintessence Int. 2016;47:93-101

38. Kim HJ, Park SH. Measurement of the internal adaptation of resin composites using micro-CT and its correlation with polymerization shrinkage. Oper dent. 2014;39:e57-70

https://doi.org/10.2341/12-378-L

39. Tay FR, Gwinnett AJ, Pang KM, Wei SH. Resin permeation into acid-conditioned, moist, and dry dentin: a paradigm using water-free adhesive primers. J Dent Res. 1996;75:1034-1044

https://doi.org/10.1177/00220345960750040601

40. Furness A, Tadros MY, Looney SW, Rueggeberg FA. Effect of bulk/incremental fill on internal gap formation of bulk-fill composites. J Dent. 2014;42:439-49

https://doi.org/10.1016/j.jdent.2014.01.005

41. Fronza BM, Rueggeberg FA, Braga RR, Mogilevych B, Soares LE, Martin AA,Ambrosano G, et al. Monomer conversion, microhardness, internal marginal adaptation, and shrinkage stress of bulk-fill resin composites. Dent Mater. 2015;31:1542-1551 https://doi.org/10.1016/j.dental.2015.10.001

42. Schenkel AB, Peltz I, Veitz-Keenan A. Dental cavity liners for Class I and Class II resin-based composite restorations. Cochrane Database Syst Rev. 2016;10:CD010526 https://doi.org/10.1002/14651858.CD010526.pub2

43. Perdigão J, Geraldeli S, Hodges JS. Total-etch versus self-etch adhesive: effect on postoperative sensitivity. J Am Dent Assoc. 2003;134:1621-1629

https://doi.org/10.14219/jada.archive.2003.0109

44. Scotti N, Bergantin E, Giovannini R, Delbosco L, Breschi L, Migliaretti G, et al. Influence of multi-step etch-and-rinse versus selfetch adhesive systems on the post-operative sensitivity in mediumdepth carious lesions: An in vivo study. Am J Dent. 2015;28:214-18

45. Browning WD, Blalock JS, Callan RS, Brackett WW, Schull GF, Davenport MB, Brackett MG.Postoperative sensitivity: a comparison of two bonding agents. Oper Dent. 2007;32:112-17

https://doi.org/10.2341/06-58

46. Yousaf A, Aman N, Manzoor MA, Shah JA, Dilrasheed. Postoperative sensitivity of self etch versus total etch adhesive. J Coll Physicians Surg Pak. 2014;24:383-386

47. Amin M, Naz F, Sheikh A, Ahmed A. Postoperative sensitivity in teeth restored with posterior dental composites using self-etch and total-etch adhesives. J Pak Dent Assoc. 2015;24:22-28

48. Reis A, Dourado Loguercio A, Schroeder M, Luque-Martinez I, 
Masterson D, Cople Maia L. Does the adhesive strategy influence the postoperative sensitivity in adult patients with posterior resin composite restorations? A systematic review and meta-analysis. Dent Mater. 2015;31:1052-1067

https://doi.org/10.1016/j.dental.2015.06.001

49. Schroeder M, Correa IC, Bauer J, Loguercio AD, Reis A. Influence of adhesive strategy on clinical parameters in cervical restorations: A systematic review and meta-analysis. J Dent. 2017;62:36-53 https://doi.org/10.1016/j.jdent.2017.05.006

50. Koshiro K, Inoue S, Sano H, De Munck J, Van Meerbeek B. In vivo degradation of resin-dentin bonds produced by a self-etch and an etch-and-rinse adhesive. Eur J Oral Sci. 2005;113:341-48 https://doi.org/10.1111/j.1600-0722.2005.00222.x

51. Ferracane JL. Resin composite-state of the art. Dent Mater. 2011;27:29-38

https://doi.org/10.1016/j.dental.2010.10.020

52. Auschill TM, Koch CA, Wolkewitz M, Hellwig E, Arweiler NB. Occurrence and causing stimuli of postoperative sensitivity in composite restorations. Oper Dent. 2009;31:3-10

https://doi.org/10.2341/08-7

53. Shortall AC, Palin WM, Jacquot B, Pelissier B. Advances in light curing units, four generations of led lights and clinical implications for optimizing their use, part2.From present to future. Dent Update. 2012;39:13-22

https://doi.org/10.12968/denu.2012.39.1.13

54. Dunne SM, Millar BJ. Effect of distance from curing light tip to restoration surface on depth of cure of composite resin. Prim Dent Care. 2008; $15: 147-52$

https://doi.org/10.1308/135576108785891150

55. Leprince JG, Palin WM, Vanacker J, Sabbagh J, Devaux J, Leloup G. Physico-mechanical characteristics of commercially available bulkfill composites. J Dent. 2014;42:993-1000 https://doi.org/10.1016/j.jdent.2014.05.009

56. Alrahlah A, Silikas N, Watts DC. Post-cure depth of cure of bulk fill dental resin-composites. Dent Mater. 2014;30:149-54 https://doi.org/10.1016/j.dental.2013.10.011

57. Sharma S, Padda BK, Choudhary V. Comparative evaluation of residual monomer content and polymerization shrinkage of a packable composite and an ormocer. J Conserv Dent. 2012;15:161-65 https://doi.org/10.4103/0972-0707.94592

58. Hamid A, Hume W.R. The effect of dentine thickness on diffusion of resin monomers in vitro. J Oral Rehabil.1997;24:20-25 https://doi.org/10.1046/j.1365-2842.1997.00490.x
59. Giachetti L, Scaminaci Russo D, Bambi C, Grandini R. A review of polymerization shrinkage stress: current techniques for posterior direct resin restorations. J Contemp Dent Pract. 2006;7:79-88

60. Dos Santos GO, Dos Santos ME, Sampaio EM, Diass KR, Da Silva EM. Influence of C-factor and light-curing mode on gap formation in resin composite restorations. Oper Dent. 2009;34:544-50 https://doi.org/10.2341/08-035-L

61. Opdam NJ, Feilzer AJ, Roeters JJ, Smale I. Class I occlusal composite resin restorations: in vivo post-operative sensitivity, wall adaptation, and microleakage. Am J Dent. 1998;11:229-34

62. Unemori M, Matsuya Y, Akashi A, Goto Y, Akamine A. Composite resin restoration and postoperative sensitivity: clinical follow-up in an undergraduate program. J Dent. 2001;29:7-13

https://doi.org/10.1016/S0300-5712(00)00037-3

63. Fusayama T. New concepts in operative dentistry. Chicago: Quintessence, 1980

64. Akpata ES, Sadiq W. Post-operative sensitivity in glass-ionomer versus adhesive resin-lined posterior composites. Am J Dent. $2001 ; 14: 34-38$

65. Schenkel AB, Peltz I, Veitz-Keenan A. Dental cavity liners for Class I and Class II resin-based composite restorations. Cochrane Database Syst Rev. 2016 Oct 25;10:CD010526

https://doi.org/10.1002/14651858.CD010526.pub2

66. Trushkowsky R. Restoration of a cracked tooth with a bonded amalgam. Quintessence Int. 1991;22:397-400

67. Mondelli J, SteagallL, Ishikiriama A. Fracture strength of human teeth with cavity preparations. J Prosthet Dent. 1980;433:419-22 https://doi.org/10.1016/0022-3913(80)90213-9

68. Banerji S, Mehta SB, Millar BJ. Cracked tooth syndrome. Part 1: aetiology and diagnosis. Br Dent J. 2010;208:459-63 https://doi.org/10.1038/sj.bdj.2010.449

69. Opdam NJ, Roeters FJ. The effectiveness of bonded composite restorations in the treatment of painful, cracked teeth: six-month clinical evaluation. Oper Dent. 2003;28:327-33

70. Porto I. Post-operative sensitivity in direct resin composite restorations: clinical practice guidelines. Ind J Rest Dent. 2012;1:112 